\title{
Promotion of comfort within the families of women submitted of mastectomy mastectomy
}

\section{Promoção do conforto no seio familiar da mulher submetida a mastectomia}

\author{
Ana Cristina F. Terceiro ${ }^{1}$, Sónia I.C. Costa Matias' ${ }^{1}$, Maão Fernandes ${ }^{1,2}$

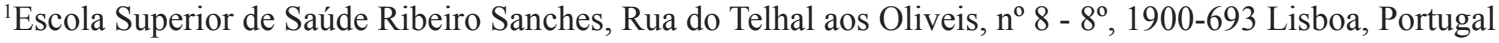 \\ ${ }^{2} \mathrm{CBIOS}$ - Research Center for Health Science and Technologies, Universidade Lusófona, Campo Grande, 376, 1749-024, \\ Lisboa, Portugal \\ Email: maria.fernandes@erisa.pt
}

\begin{abstract}
Breast cancer is one of the most feared oncological diseases and also one that causes great suffering on women and their families. In some cases this disease may require a mastectomy. As a surgical procedure that involves mutilation, a mastectomy changes women's perception of their own bodies, causing a great deal of suffering In this context, therefore, the support of their families and nurses is absolutely crucial.

This study aims to identify discomforts caused by mastectomy in women and the promotion of respective comfort by their families and nursing care, while answering the question: "How to promote familial comfort for mastectomized women?" The study consists of exploratory-descriptive qualitative research with an intentionally non-probabilistic sample. Five semi-structured and recorded audio interviews were conducted in an oncological association to women who have been mastectomized for more than one year and who have lived the process in a familial context. The collected data were investigated according to Bardin's content analysis method. This analysis resulted in the following categories: spoken feelings by women mastectomized, post-mastectomy impact, adopted strategies, and the role of nurses. On the perspective of a future nurse, this study allowed for the acquisition of tools for the active intervention for promotion of the comfort for these women and their families.
\end{abstract}

Keywords: Mastectomy, Feelings, Impact, Adopted strategies and Nurse’s role.

\section{Resumo}

O carcinoma da mama é uma das doenças oncológicas que mais exaspera sofrimento e medo de morte por parte da mulher e sua família, podendo levar à necessidade de realizar mastectomia. Sendo um processo cirúrgico que acarreta a mutilação, causa sofrimento sobre a auto-percepção que a mulher tem do corpo, e neste contexto, o apoio da família e dos enfermeiros é fundamental. Este estudo pretende identificar desconfortos causados pela mastectomia na mulher e seus familiares e cuidados de enfermagem que promovem o respetivo conforto, respondendo à questão "Como promover o conforto no seio familiar da mulher mastectomizada?". Trata-se de uma abordagem qualitativa, de caracter exploratório-descritivo, com uma amostra não probabilística, intencional. Foram realizadas cinco entrevistas, semiestruturadas e áudio-gravadas, numa Associação de foro oncológico, a mulheres mastectomizadas há mais de um ano, que vivenciaram o processo em contexto familiar. Os dados recolhidos foram analisados segundo o método de análise de conteúdo de Bardin.

Como achados emergiram as categorias: Sentimentos verbalizados pelas mulheres mastectomizadas, Impacto pós-mastectomia, Estratégias adotadas e o Papel do Enfermeiro pós e pré-mastectomia. Este estudo permitiu adquirir conhecimentos e ferramentas para a intervenção da enfermagem, na promoção do conforto destas mulheres e suas famílias.

Palavras-chave: Mastectomia, Sentimentos, Impacto, Estratégias adotadas e Papel do enfermeiro. 


\section{Introduction}

The breast is probably one of the most symbolic and sensitive elements of a woman's body, pronounced by singular characteristics in women adult life related with sexuality, sensuality, maternity, and in all of feminine identity ${ }^{[1]}$. It is important to identify how a woman sees her body, and specifically how she sees her breasts, in such a way that it can reflect her own self-esteem and the relationship(s) that she establishes with others ${ }^{[2]}$.

Breast cancer is the most frequent tumour in Portuguese women and the first cause of mortality by neoplasia,_both nationally and worldwide, thus being a great health concern ${ }^{[3]}$. Currently in Portugal, with five million females, 4,500 new cases of breast cancer appear every year. This corresponds to 11 new cases every day, and it (breast cancer) kills four women daily ${ }^{[4]}$.

Cumulatively, the treatment of breast cancer includes mastectomy, impacting women by changing their everyday lives as well as those within their family, because both deal with this disease. All of these changes necessarily involve discomfort, which is shared by the woman and her family ${ }^{[5]}$.

Considering the high number of women undergoing mastectomy, and the consequences to which it leads (e.g., change of image, relationships with others, affecting both the women and their families) the nursing interventions to promote comfort are important, allowing stakeholders to adapt to any process experienced. ${ }^{[5]}$. Comfort was previously a focus of Florence Nightingale (1859) as the objective of care. Katherine Kolcaba presents a definition of holistic comfort that manifests from the meeting of basic human needs, allowing the evaluation of discomforts ${ }^{[6]}$. This theory covers the different dimensions of the person and can be applied to various areas of intervention within nursing care and in particular to the person who experiences the comfort / discomfort.

The Kolcaba theory ${ }^{[6]}$ has two dimensions: the first refers to a Comfort state and the second to the Context in which comfort happens. The first dimension has three different Comfort states, namely the Relief (feeling of having a need for comfort satisfied), Tranquillity (includes the state of calm or contentment) and Transcendence (experience above the physical or normal and condition in which a person can overcome a problem or pain). In the second dimension, four Contexts exist: the Physical context (physical sensations, homeostatic mechanisms and immune functions), the Psychosocial (internal self-awareness, including self-esteem, selfconcept, sexuality, the meaning in one's life and the combination of mental, emotional and spiritual states),

\section{Introdução}

A mama é, provavelmente, a parte do corpo da mulher mais carregada de elementos simbólicos e sensíveis, marcada por características singulares na vida da mulher adulta em relação à sua sexualidade, sensualidade, maternidade e no todo da sua identidade feminina ${ }^{[1]}$. A forma como a mulher vê e encara as mamas pode constituir um indicador da sua própria autoestima, refletindo-se também no relacionamento estabelecido com os outros ${ }^{[2]}$.

O carcinoma da mama é o tumor mais frequente entre as mulheres portuguesas e a primeira causa de morte por neoplasia, tanto a nível nacional como mundial, mantendo-se como uma grande preocupação de saú$\mathrm{de}^{[3]}$. Atualmente em Portugal, com uma população feminina de cinco milhões, surgem 4.500 novos casos de Carcinoma da Mama por ano, equivalente a 11 novos casos por dia, morrendo quatro mulheres com esta doença diariamente ${ }^{[4]}$.

Cumulativamente, o tratamento do carcinoma da mama inclui a mastectomia, acarretando impacto na mulher, alterando o seu quotidiano, assim como no seu contexto familiar, pois ambos lidam com esta doença. Todas essas alterações implicam necessariamente um desconforto, que é partilhado pela mulher e sua família ${ }^{[5]}$.

Considerando o elevado número de mulheres submetidas a mastectomia e as consequências (e.g.: alteração da imagem, da relação com outrem,...) a que a mesma conduz (tanto na mulher, como na família) são importantes as intervenções de enfermagem de forma a promover o conforto, possibilitando uma adaptação a todo o processo experienciado por todos os intervenientes ${ }^{[5]}$. O conforto já era alvo de atenção por parte de Florence Nightingale (1859), sendo este considerado objeto a ser atingido nos cuidados prestados. Katherine Kolcaba ${ }^{[6]}$ apresenta-nos uma definição de conforto holístico, manifestado pelo resultado do encontro das necessidades humanas básicas, permitindo desta forma avaliar os desconfortos. A presente teoria abrange as diferentes dimensões da pessoa, podendo ser aplicada às diversas áreas de intervenção dos cuidados de enfermagem e em específico à pessoa que experiencia o conforto/ desconforto.

A teoria de Kolcaba ${ }^{[6]}$ tem duas dimensões, a primeira refere-se ao estado de Conforto e a segunda ao Contexto em que o conforto acontece. À dimensão um (I) correspondem três estados do Conforto, nomeadamente o Alívio (sensação de ter uma necessidade de conforto satisfeita), Tranquilidade (contempla o estado de calma ou contentamento) e Transcendência (experiência a nível superior ao físico ou normal e condição na qual 
Social (interpersonal relationships and family, including financial, educational, and personal health care, as well as family tradition, cultural, ritual and religious practices) and Environmental (focus on external conditions and influence of the immediate environment, including colours, lighting, sound / noise, odour, temperature, natural and artificial elements). Combining the four Contexts and the three Comfort states, results in a table with twelve cells, allowing Comfort aspects derived from the states of the crossing with the Context ${ }^{[6]}$. The analysis of the dimensions of the Kolcaba theory ${ }^{[6]}$ allows nurses, regardless of their professional practice area, to establish their own comfort tools based on observed and/or verbalized needs both on an individual and/or family context, considering the individual patient and their information needs ${ }^{[7]}$.

The nurse nnterventions arise in order to provide health care to the user, family or the population, and in such as way provide comfort to them. Thus, the nurse must "identify, plan and implement actions that correspond to the specific needs of the individual and respective family" $[8]$.

The support of their family and their social circle is important to mastectomised women, but the expertise of a nurse can allow to proper management of the problems that emerge from the mastectomy, transmitting confidence to face the whole process ${ }^{[9]}$. It is known that nurses should develop interventions that target the women with mastectomies and their families, promoting expressive communication of emotions to encourage active listening, establish a dynamic relationship, as well as interactive roles ${ }^{[10]}$. Thus, nurses develop skills that will provide the comfort to the woman and her family in particular to adapt to mastectomy process.

\section{Materials and Methods}

Starting from the research question: "How can comfort be promoted in the family of the woman subjected to mastectomy?" the following general and specific objectives were established: to promote comfort in the family of the woman who have underwent mastectomy a pessoa consegue suplantar um problema ou dor). $\mathrm{Na}$ dimensão dois (II) apresentam-se quatro Contextos: o Físico (sensações físicas, mecanismos homeostáticos e funções imunes); o Psicossocial (consciência interna de si mesmo, incluindo a autoestima, o autoconceito, a sexualidade, o significado na vida de alguém e a combinação do estado mental, emocional e espiritual); o Social (relações interpessoais, familiares, sociais, incluindo questões financeiras, educação, cuidado de saúde pessoal, assim como tradições familiares, culturais, rituais e práticas religiosas); e o Ambiental (foco no ambiente, nas condições e influências externas, incluindo cores, iluminação, sons/ruídos, odor, temperatura, elementos naturais e artificiais). Da combinação dos quatro Contextos, com os três estados do Conforto, obtém-se uma tabela com doze células, permitindo que os aspetos do Conforto derivem do cruzamento dos estados com os Contextos ${ }^{[6]}$.

A análise das dimensões da Teoria de Kolcaba ${ }^{[6]}$, permite aos enfermeiros, independentemente da área de exercício profissional, definirem as suas próprias ferramentas de conforto com base nas necessidades observáveis e/ou verbalizadas quer em contexto individual e/ ou no familiar, considerando a sua individualidade e as suas necessidades de informação ${ }^{[7]}$.

As Intervenções do Enfermeiro surgem com o intuito de prestar cuidados de saúde ao utente, família ou à população, proporcionando o conforto aos mesmos. Assim, o enfermeiro deve "identificar, planear e executar ações que correspondem às necessidades específicas do indivíduo e família" ${ }^{[8]}$.

Revela-se importante o apoio da própria família e do seu ciclo social, mas a competência de um enfermeiro pode permitir gerir corretamente os problemas que emergem da mastectomia, transmitindo confiança, para enfrentar todo o processo ${ }^{[9]}$. Sabe-se ainda que o enfermeiro deve desenvolver intervenções que englobem a mulher mastectomizada e a sua família, promovendo a comunicação expressiva de emoções, incentivar à escuta ativa, estabelecer uma relação dinâmica, assim como a interação de papéis ${ }^{[10]}$. Logo o enfermeiro desenvolverá competências que irão proporcionar o conforto, da mulher e família, nomeadamente no processo de adaptação à mastectomia.

\section{Materiais e Métodos}

Partindo da pergunta de investigação "Como promover o conforto no seio familiar da mulher submetida a mastectomia?", foram estabelecidos os seguintes objetivos geral e específicos: promover o conforto no seio familiar da mulher submetida a mastectomia e dos objetivos 
and related specific objectives; identify discomfort in women who have undergone mastectomy; identify the impact of the discomforts in women and in the family in the post- mastectomy period; and identify the nursing care that promotes comfort in women undergoing mastectomy and their families .

We developed a qualitative study, exploratory and descriptive. The sample is not probabilistic, rather, intentional by convenience, consisting of five women who underwent mastectomy for over a year and experienced the process in family context and who belonged with an oncological association.

The data were collected between October and November 2014 by semi-structured, audio-recorded interviews, with scripts of assistance, and analysed according to the method of analysis of content by Bardin ${ }^{[11]}$.

The ethical principles were respected by obtaining the written authorization of the institution and informed and clear consent of participants.

\section{Results}

The participants had an average age of 48 years at the time of interview, and 37.4 years at the time of the mastectomy. Four participants were married and divorced. Regarding profession, one was retired and the remaining were still employed. Categories emerged from the analysis of the study findings: spoken feelings by mastectomised women, impact post-mastectomy, adopted strategies and the role of the nurse in the post and pre-mastectomy, as shown in Table 1 . específicos; identificar os desconfortos nas mulheres submetidas a mastectomia; identificar o impacto dos desconfortos na mulher e no seio familiar no período pós-mastectomia; e identificar os cuidados de enfermagem que promovam o conforto nas mulheres submetidas a mastectomia e dos seus familiares.

Desenvolvemos um estudo de abordagem qualitativa, exploratório-descritivo.

A amostra é intencional por conveniência, constituída por cinco mulheres mastectomizadas há mais de um ano, que vivenciaram o processo em contexto familiar e pertencentes a uma Associação de foro oncológico.

Os dados foram recolhidos, entre outubro e novembro de 2014, através de entrevistas semiestruturadas e áudio-gravadas, com auxílio de guião e analisados segundo o método de Bardin ${ }^{[11]}$.

Foram respeitados os princípios éticos através da obtenção da autorização formal da Instituição e do consentimento informado e esclarecido das participantes.

\section{Resultados}

As participantes com idade média de 48 anos no momento da entrevista e 37,4 anos no momento da realização da mastectomia, quatro são casadas e uma é divorciada, uma está reformada e as restantes desenvolvem atividade laboral.

Da análise dos dados emergem as Categorias: Sentimentos Verbalizados pelas Mulheres Mastectomizadas, Impacto Pós-mastectomia, Estratégias Adotadas e o Papel do Enfermeiro no Pós e no Pré-mastectomia, conforme se observa na Tabela 1.

Table 1/ Tabela 1. Categories emerged during the interviews content analysis Categorias emergidas aquando da análise de conteúdo das entrevistas

Spoken Feelings by Women Mastectomized

Sentimentos Verbalizados pelas Mulheres Mastectomizadas

Post-mastectomy Impact

Impacto Pós-mastectomia

Adopted Strategies

Estratégias Adotadas

The Nurses' Role

Papel do Enfermeiro no Pós-mastectomia

The Nurses' Role

Papel do Enfermeiro no Pré-mastectomia 
In the category spoken feelings by mastectomised women, which are intrinsically linked to the body as a symbol, positive feelings and negative neelings were identified.

Positive Feelings are part of the Relief and Hope. The relief comes "because it would "solve" my problem" (E2:13). Hope emerges "I was trying to see the positive side, and living one day at a time" (E1:9).

The negative feelings emerge from fear, sadness, death, revulsion, loss, shock, disgust, anxiety, uncertainty, concern, pain, depression, anxiety, embarrassment, inferiority, insecurity and negative attitude. There is evidence of "everything is living in fear" (E3:29). The "sadness that (apparently) has no end ..." (E3:15), "(There) are days where sorrow is sometimes earned" (E2:33). Death relates to aspects such as: "leaving my daughters" (E1:3) "fear of dying during surgery" (E2:17). The revolt is reflected in the verbatim "constantly asked why us and not others?" (E3:3). The loss of the breast revealed by expressions: "the emptiness I felt the lack of a part of me, part of my femininity" (E1:13). Following the loss, comes the "(...) shock when we reach out and just feel the bandage and then a complete hole" (E3:33). The "disgust when I saw myself in the mirror after the surgery" (E2:15) is characterised by loss of sexual attractiveness and fear that her husband feels disgusted by the presence of the scar. This refers to the uncertainty that is transmitted by "very difficult time" (E4:3). The self-awareness of breast loss relates to embarrassment phase, as evidenced one of the speeches: "and I knew it came to show me embarrassed" (E3:13). You relieved "I knew and it came to me (feeling) lower" (E3:14), feeling of inferiority that is intrinsically linked to breast loss. The concern is patent "(...) the result of pathological anatomy" (E4:9), preceding a sense of hope at the outcome "Hope everything goes well" (E4:9). Pain is one of the "greatest fears" (E4:34). It also shows insecurity "the truth is that we feel unsafe at all, it seems we do not know to handle anything" (E3:28). It is further demonstrated a negative attitude "I know that at the same time (...) not dealt well with the loss of the breast" (E4:16).

In the category Impact Post-mastectomy emerged changes in Body Image, the Self Context, Family, Children and Social Context, which are associated with the impact of mastectomy not only for women but also for their family and their social context.

In Body Image arises mutilation, the need to hide the body, the symbology of the Breast, the decrease of SelfEsteem and the Confrontation with the prosthesis.

Mastectomy is defined by one as "human being mutilated, who have no breast" (E3:8). From the impact of mutilation emerges the need to hide the body "after los-
A categoria Sentimentos Verbalizados pelas Mulheres Mastectomizadas, que estão intrinsecamente relacionados com o corpo como símbolo, advém de Sentimentos Positivos e Negativos.

Os Sentimentos Positivos integram o Alívio e a Esperança. O Alívio surge "porque ia "resolver" o meu problema" (E2:13). A Esperança emerge de "fui tentando ver o lado positivo, e vivendo um dia de cada vez". (E1:9).

Os Sentimentos Negativos emergem do Medo, Tristeza, Morte, Revolta, Perda, Choque, Repugnância, Angústia, Incerteza, Preocupação, Dor, Depressão, Ansiedade, Embaraço, Inferioridade, Insegurança e Atitude Negativa. Evidencia-se "tudo é vivido com medo" (E3:29). A "tristeza que (parece) não acabar..." (E3:15), " (há) dias onde a tristeza por vezes ganhava" (E2:33). A morte relaciona-se com aspetos tais como: "deixar as minhas filhas" (E1:3) "medo de morrer durante a cirurgia" (E2:17). A revolta, está patente no verbatim "Perguntamos constantemente porquê a nós e não a outros?" (E3:3). A perda da mama revelada por expressões como "aquele vazio que senti, a falta de uma parte de mim, parte da minha feminilidade" (E1: 13). Subsequente à perda, advém o " (...) choque quando colocamos a mão e só sentirmos a ligadura e depois um buraco completo" (E3:33). A "repulsa quando me vi ao espelho depois da cirurgia" (E2:15) é caracterizada pela associação de perda da atração sexual e receio que o marido sinta repugnância pela presença da cicatriz. Esta remete para a incerteza que é transmitida por "momento muito difícil" (E4:3). A auto-consciencialização da perda da mama, relaciona-se com fases de embaraço, como evidencia um dos discursos, "eu sabia e isso chegava para me mostrar embaraçada" (E3:13). Igualmente é relevado "eu sabia e isso chegava para me (sentir) inferior” (E3:14), sentimento de inferioridade que está intrinsecamente associado à perda da mama. A preocupação está patente com "(...) o resultado da anatomia patológica" (E4:9), precedendo um sentimento de esperança face ao resultado "esperança que corra tudo bem" (E4:9). A dor é um dos "maiores receios" (E4:34). Evidencia-se igualmente insegurança "a verdade é que nos sentimos inseguras com tudo, parece que não sabemos lidar com nada" (E3:28). É ainda demonstrada atitude negativa "sei que ao mesmo tempo (...) não lidei bem com a perda da mama" (E4:16).

$\mathrm{Na}$ categoria Impacto Pós-mastectomia emergiram as alterações na Imagem Corporal, Contexto do Eu, Família, Filhos e Contexto Social, que estão associadas ao impacto que a mastectomia terá não só para a mulher, mas também para a sua família e ao seu contexto social. A Imagem Corporal surge da própria Mutilação, da necessidade de Esconder o corpo, da Simbologia da 
ing breast, I started using only clothes without neck, still felt the brunt" (E2:25). Want to hide body, refers to the importance of breast as a symbol of femininity, such as "Lack of something that once served to breast feed my daughters" (E1:1)." Evidence of decreased self-esteem "I felt less of a woman" (E5:3). After mastectomy women feel the need to fill the "void", and the options may appealing for external or internal prosthesis, however "after the breast is not mine" (E1:18), contributing in part to make the experience any impact on their body image.

In the context of self, from the confrontation of Self with Self, emerged regressions, crisis / deadlocks and uncertainties in face of the future.

Mastectomy causes devastating impact, "is an overwhelming feeling I had depression, I took immense drugs" (E1:6). Setbacks can also arise, "everything I though overpassed, came back in no time" (E2:7). The crisis / stalemate is evident, "I was entering a war with myself" (E3:8). Finally, the verbatim "we do not know whether we will regain our usual life" (E2:20) explains trying to overcome / conquer the whole process, manifesting uncertainty over the future.

The Impact of Mastectomy in Family Context is experienced by the shock expression, the Interpersonal Relationship in Sexuality / Intimacy in Conjugality and Disability.

The impact of mastectomy family context is evidenced in that "is to have all and lose all" (E3:20), conveying a feeling of shock. Interpersonal relationship is established with the men: "My husband was an exemplary help (...) always gave me strength, has always been on my side, whenever he saw me sad, was there to give me a little gift to show me that I was not in that boat alone, which would always have his support (...) gave support and strength to face myself in the mirror " (E4:24). The change in women's lives related to intimacy with their partner is manifested by "did not want my husband to see me without breast with that horrible scar." (E3:22). Underlying the change in body image, there is marital doubt "after just thought of my marriage (...) would my marriage endure?" (E1:23). Moreover, the impact failure "had difficulty making some tasks" (E2:34). Recall that subsequent to mastectomy process, many women need to haveaxillary dissection performed, which can accentuate this disability.

Impact on the Family Context (Children) also occurs, including the Interpersonal Relationship and Caring established with the children not understanding the whole process: "(...) Is a lot for a child, because the school classmates asked him why I had no hair, which ended up mocking him" (E2:36), which brings out a caring phase because " my children ( ... ) felt a difference, I
Mama, da Diminuição da Autoestima e do Confronto com a Prótese.

A mastectomia representa "ser humano mutilado, que não têm peito" (E3:8). Deste impacto da mutilação emerge a necessidade de esconder o corpo "depois de perder mama, passei a usar só roupa sem decote, ainda sentia mais o impacto" (E2:25). Querer esconder o corpo, remete para a importância da mama como símbolo da feminilidade, como a "falta de algo que em tempos serviu para amamentar as minhas filhas" (E1:1). Evidencia-se a diminuição da autoestima "senti-me menos mulher" (E5:3). Após a mastectomia a mulher sente necessidade de preencher o "vazio", e perante as opções poderá recorrer à prótese externa ou interna, contudo "afinal a mama não é a minha" (E1:18), contribuindo em parte para tornar a vivenciar todo o impacto na sua imagem corporal.

O Contexto do Eu, emerge do próprio Confronto com o $\mathrm{Eu}$, os Retrocessos, Crises/Impasses e Incertezas Face ao Futuro.

A mastectomia acarreta impactos devastadores "é um sentimento avassalador, tive depressão, tomei imensos medicamentos" (E1:6). Também podem surgir retrocessos "tudo o que tinha superado, voltou num espaço de segundos" (E2:7). A crise/impasse evidencia-se: "estava a entrar numa guerra comigo própria" (E3:18). Por último, o verbatim "não sabermos se vamos recuperar a nossa vida habitual" (E2:20), explica o superar/vencer todo o processo, manifestando incerteza face ao futuro.

O Impacto da Mastectomia em Contexto Familiar advém de Choque, Relação Interpessoal, Sexualidade/Intimidade, Conjugalidade e Incapacidade.

O impacto da mastectomia em contexto familiar é evidenciado na medida em que "é ter tudo e perder tudo" (E3:20), transmitindo um sentimento de choque. A relação interpessoal é estabelecida com o companheiro " $\mathrm{O}$ meu marido foi uma ajuda exemplar (...) sempre me deu força, esteve sempre do meu lado, sempre que me via triste, estava lá para me dar um miminho, para me mostrar que não estava naquele barco sozinha, que teria sempre o apoio dele (...) deu apoio e força para me encarar ao espelho" (E4:24). A alteração na vida das mulheres relacionada com a intimidade com o parceiro manifesta-se por "não queria que o meu marido me visse sem mama, com aquela cicatriz horrível." (E3:22). Subjacente à alteração da imagem corporal, a conjugalidade do casal é colocada em dúvida "depois pensei logo no meu casamento (...) iria o meu casamento aguentar?" (E1:23). Acresce o impacto incapacidade "tinha dificuldade em fazer algumas tarefas" (E2:34). Lembremos que subsequentemente ao processo de mastectomia, muitas mulheres necessitam de realizar o esvaziamento axilar, o que pode acentuar esta incapacidade.

Advém também o impacto no Contexto Familiar (Filhos), nomeadamente na Relação Interpessoal estabelecida e na Inquietação que a mulher vivencia pela (in)compreensão dos filhos de todo o processo: “(...) é muito para uma criança, até porque os coleguinhas de escola lhe perguntavam porque não tinha cabelo, que acabavam por gozar com ele" (E2:36), o que faz emergir uma fase de inquietação pois "meus filhos (...) sentiram diferença, eu andava mais cansada, perdi 
walked more tired, I lost my hair, then the breast, was not so available to play with them ..." (E4:26).

Also comes the Social Context, emerged from Confrontation "I even dealt well with the disease, but the gaze of others are very hard, make us feel monsters, as if we were different" (E2:28).

In the category Strategies Adopted the existence of various strategies used by women were confirmed in order to adapt not only to changes in physical appearance, but also to the disease: Coping and Self Concept.

In Coping arises the recognition by the Family Support, Acceptance, Positive Attitude, the Implementation of Projects, the Sharing Experiences, Information Search,

Change of Individuality and Lived clarification.

We realize that women with mastectomies recognize that both the husband and daughters and extended family convey toher the courage to face this process: "My husband is a spectacular person and was always on my side, always showed me the positive side of all " (E1:26), "(the daughters) who gave me deep down courage to continue to fight and win" (E1:12), and "the family was very important in this process ... to them very owe them" (E3:19). The acceptance of mastectomy is mentioned, "then I adapted myself to the reality I faced the mirror again and again ... one lives one day at a time ... and is fighting constantly" (E3:34), "accept is half the battle to overcome" (E4:7). Verbatim report that having a positive attitude, helps overcome the whole process of mastectomy, mentioning that "I never stopped doing anything, always continued to do everything at home, keep me busy" (E1:21). The stretch "back to work allowed me to occupy the head and distracting me..." (E4:20), translates the feeling of productivity and logo possibility of realization of previous projects. It is noted that women have the possibility to share their feelings and emotions "to share with others, know their experiences, give us another view of the whole process" (E4:39). Also stresses the demand of obtaining the earliest possible answers, "so he knew the disease was soon to the internet for answers" (E4:31). It also highlights the change of individuality "Today I feel another" (E1:16). Clarification of living emerges from the report: "You know a funny thing, I always wanted to know all of my health, and when I discovered the cancer wanted to know everything about it" (E3:26).

The Self Concept emerges from Breast Reconstruction or Prosthesis which becomes the symbol means the return of the feminine image "which led me to decide to do breast reconstruction was when summer came and went to the beach" (E2:6).

The nurse, as part of the adaptation of the woman and her family to the mastectomy process, raised the Category Role of Nurses in post-mastectomy by demonstrating Relational Skills and Instrumental skills. o cabelo, depois a mama, não tinha tanta disponibilidade para brincar com eles... " (E4:26).

Igualmente advém o Contexto Social, surgido do Confronto "eu até lidava bem com a doença, mas o olhar dos outros são muito duros, fazem-nos sentir monstros, como se fossemos diferentes." (E2:28).

$\mathrm{Na}$ categoria Estratégias Adotadas pode-se constatar a existência de várias estratégias utilizadas pela mulher no sentido de se adaptar não só às alterações da aparência física, mas também à própria doença: o Coping e a Autoimagem.

O Coping surge do Reconhecimento pelo Apoio Familiar, Aceitação, Atitude Positiva, a Concretização de Projetos, a Partilha de Experiências, Procura de Informação, Alteração da Individualidade e Clarificação do Vivido.

Percebemos que a mulher mastectomizada reconhece que tanto o marido, como filhas e restante família lhe transmitem coragem para enfrentar todo este processo: "O meu marido, é uma pessoa espetacular, e esteve sempre do meu lado, mostrou-me sempre o lado positivo de tudo" (E1:26), "(as filhas) que me deram, no fundo, coragem para continuar, para lutar e vencer" (E1:12), e "a família foi muito importante neste processo... a eles muito lhes devo" (E3:19). A aceitação da mastectomia é mencionada: "depois adaptei-me à realidade, encarei o espelho uma e outra vez... vive-se um dia de cada vez... e luta-se constantemente" (E3:34), " aceitar é meio caminho andado para ultrapassar." (E4:7). Os verbatins referem que ter uma atitude positiva, ajuda a ultrapassar todo o processo de mastectomia, mencionando que "nunca deixei de fazer nada, continuei sempre a fazer tudo em casa, a manter-me ocupada" (E1:21). O excerto " voltar ao trabalho permitiu-me ocupar a cabeça e abstrair-me de tudo..." (E4:20), traduz o sentimento de produtividade e logo possibilidade de concretização de projetos anteriores. Releva-se o facto da mulher ter possibilidade de partilhar os seus sentimentos e emoções "partilhar com outros, saber as suas experiências, dá-nos outra visão de todo este processo" (E4:39). Também se salienta a procura da obtenção de respostas o mais atempadamente possível, "assim que soube da doença, foi logo para a internet procurar respostas" (E4:31). Evidencia-se igualmente a alteração da individualidade "Hoje sinto-me outra" (E1:16). A clarificação do vivido emerge do relato: "Sabe uma coisa engraçada, eu sempre quis saber tudo da minha saúde, e quando descobri o cancro queria saber tudo sobre ele" (E3:26).

A Autoimagem emerge de Reconstrução Mamária ou Prótese o qual se torna o meio de retorno do símbolo da imagem feminina "o que me levou a decidir a fazer a reconstrução mamária, foi quando chegou o verão e fui a praia" (E2:6).

$\mathrm{O}$ enfermeiro como parte integrante na adaptação da mulher e sua família ao processo da mastectomia fez surgir a Categoria Papel do Enfermeiro no pós-mastectomia evidenciando-se as suas Competências Relacionais e Instrumentais. 
In Relational Competence, Availability, Active Listening, Empathy, Family Involvement and Initiation of the Family Involvement emerge. Availability because it is evident that "nurses have always been available" (E5:16), fundamental to the therapeutic relationship. Transpires active listening, "nurses (...) above all hear us" (E4:32) and "accepts us every day, whether good or bad days, have hair or not, beautiful or ugly, never look on indifferently, looks at us with hope, wanting to help" (E3:36) brings out empathy. It also noted that "Whenever I needed to take my son to treatment, was with them I could count" (E4:21) and that the nurse was vehicle facilitation "involvement, as it were natural to my husband" (E1:32).

In the Instrumental Competence, the Comfort, Empowerment Facilitation and Social Support / Care Coordination, evidenced by verbatim as " always had a nurse beside me who reassured me" (E4:35), "were the shoulders which supported me when I felt down" (E2:39) and "provided the comfort, the reduction of our fears, information sharing " (E1:31). The nurse is as "a means of facilitating an entire adaptation to the disease" (E1:33) and "(...) themselves known institutions that could turn" (E4:37).

The findings also highlight the importance of the nurse's role in the pre-mastectomy. Thus anticipatory Care and Health Education, Concern, the Information Transmission and Active Listening were identified.

Health education is also arelief by "a nurse [to him] called because it was not going to consultation for some time, do the Pap smear and stuff, that allowed me to discover. Early cancer at an early stage" (E1:28) and "the fact that the nurses worry" (E1:29). It was also shown that "it was a nurse to my room, explain to me the surgery, which would always be together, who would do anything not to have pain." (E2:24), which allows a moment of sharing feelings of anguish, of fears about surgery, "those feelings that we do not share with anyone who we love" (E2:45), because the woman cannot always share their anxieties with the family.

\section{Discussion}

By the confrontation between the findings obtained and the dimensions of Kolcaba theory found that the feelings verbalized by Mastectomized Women emerged: Fear, Sadness, Death, Revolt, Loss, Shock, Disgust, Anguish, uncertainty, concern, Pain, Anxiety, Embarrassment, inferiority, insecurity and Negative Attitude, fall within the intersection Comfort Transcendence with the psycho-spiritual context, the Kolcaba theory.
A Competência Relacional emerge da Disponibilidade, Escuta Ativa, Empatia, Envolvimento Familiar e Desencadeamento do Envolvimento Familiar. Disponibilidade porque se evidencia que os "enfermeiros sempre se mostraram disponíveis" (E5:16), fator fundamental para a relação terapêutica. Transparece a escuta ativa: "os enfermeiros (...) acima de tudo ouvem-nos" (E4:32). e "aceita-nos todos os dias, sejam dias bons ou maus, tenhamos cabelo ou não, bonitas ou feias, nunca nos olham com indiferença, olham-nos com esperança, com vontade de ajudar" (E3:36) faz emergir a empatia. É ainda referido que "Sempre que precisei de levar o meu filho aos tratamentos, era com eles que podia contar" (E4:21) e que o enfermeiro foi veículo de facilitação do "envolvimento, por assim dizer natural do meu marido" (E1:32).

Quanto à Competência Instrumental, ela emerge de Conforto, Facilitação da Capacitação e Apoio Social/Articulação de Cuidados, evidenciados por verbatins como "tive sempre um enfermeiro ao meu lado que me tranquilizou" (E4:35), "foram os ombros onde me apoiei quando me senti em baixo" (E2:39) e "proporcionaram o conforto, a diminuição dos nossos receios, a partilha de informação" (E1:31). O enfermeiro é como "um meio facilitador de toda uma adaptação à doença" (E1:33), assim como "(...) deram a conhecer as instituições que podíamos recorrer" (E4:37).

Os achados evidenciam igualmente a importância do Papel do Enfermeiro no Pré-mastectomia a qual surgiu de Cuidados Antecipatórios que por sua vez emergiu de Educação para a Saúde, Preocupação, a Transmissão de Informação e a Escuta Ativa.

Educação para a saúde é relevada por "uma enfermeira [que lhe] ligou, porque não ia à consulta há algum tempo, fazer o papanicolau e essas coisas, que me permitiu descobrir atempada o cancro numa fase inicial" (E1:28), assim como "o facto de os enfermeiros se preocuparem" (E1:29). Também foi evidenciado que "foi uma enfermeira ao meu quarto, explicar-me a cirurgia, que ia estar sempre acompanhada, que fariam tudo para não ter dor.“ (E2:24), o que permite um momento de partilha de sentimentos, de angústias, de receios em relação à cirurgia, "aqueles sentimentos que não partilhamos com quem amamos" (E2:45), pois nem sempre a mulher consegue partilhar as suas angustias com a família.

\section{Discussão}

Mediante o confronto entre os achados obtidos e as dimensões da teoria de Kolcaba (1991) verificámos que os Sentimentos Verbalizados pelas Mulheres Mastectomizadas emergidos: Medo, Tristeza, Morte, Revolta, Perda, Choque, Repugnância, Angustia, Incerteza, Preocupação, Dor, Ansiedade, Embaraço, Inferioridade, Insegurança e Atitude Negativa, enquadram-se na intersecção do Conforto Transcendência com o Contexto da Psicoespiritual, da teoria de Kolcaba. 
For the same theory, the Comfort of Transcendence and Physical Context fit with feelings Loss and Pain. Regarding Positive Feelings, the Relief refers to the Comfort Relief and Hope for the Comfort in Tranquillity and both to the psycho-spiritual context.

Post-mastectomy Impact fits the mutilation in the Comfort of Transcendence and the Physical and psycho-spiritual context. Also in the psycho-spiritual context Hide the Body, Breast Symbology, decreased self-esteem, Confronting the prosthesis, Depression, Confronting the Self, kicks, Crisis / Deadlocks and uncertainties in facing the Future is part of the Comfort of Transcendence. The Shock, Interpersonal Relationship, Conjugality, Disability and Confrontation fall within the dimension of the Social Context and also in the Comfort of Transcendence.

The Adopted Strategies are in terms of size Comfort and Tranquillity in relief and psycho-spiritual context Acceptance, Positive Attitude, Delivering the projects, the sharing, the Change of Individuality and the Lived clarification. In the same context, but in Comfort Relief, Breast Prosthesis and Reconstruction are identified. The recognition by the Family Support and Family Support refer to the size of Kolcaba in Comfort Relief and Tranquillity and the Social Context. The Search for information is given in Relief Comfort and Transcendence and Social Context.

In the role of nurse in the Post-mastectomy period, highlighted as effective are Active Listening, Empathy, Family Involvement, triggering the Family Involvement, Comfort, Empowerment Facilitation, and Social Support / Care Coordination falling under the Comfort and Tranquillity Relief and Social context.

In the role of nurse in Pre-mastectomy period are identified the Comfort and Tranquillity Relief, Education for Health Conscious and Active Listening lying in the same social context. The Information Transmission fits the Transcendence beyond Comfort, Comfort Relief and Social Context.

\section{Conclusion}

Breast cancer affects sexuality of women in their physical and emotional dimensions, as the subsequent surgery is mutilating, and even the appearance of episodes of pain and side effects of the treatment change their self-image and self-concept and have a negative impact on identity of women and their family.
Pela mesma teoria, no Conforto da Transcendência e no Contexto Físico enquadra-se os sentimentos Perda e Dor. Em relação aos Sentimentos Positivos, o Alívio remete para o Conforto no Alívio e a Esperança para a dimensão do Conforto na Tranquilidade estando ambos para o Contexto Psicoespiritual.

No Impacto Pós-mastectomia enquadra-se a Mutilação no Conforto da Transcendência e no Contexto Físico e Psicioespiritual. Igualmente no Contexto Psicoespiritual o Esconder o Corpo, Simbologia da Mama, Diminuição da auto-estima, Confrontar a Prótese, Depressão, Confrontar o Eu, Retrocessos, Crises/Impasses e Incertezas Face ao Futuro insere-se no Conforto da Transcendência. O Choque, Relação Interpessoal, Conjugalidade, Incapacidade e Confronto enquadram-se na dimensão do Contexto Social e igualmente no Conforto da Transcendência.

As Estratégias Adotadas encontram-se ao nível da dimensão do Conforto no Alívio e Tranquilidade e Contexto Psicoespiritual a Aceitação, a Atitude Positiva, o Concretizar Projetos, a Partilha, a Alteração da Individualidade e a Clarificação do Vivido. No mesmo Contexto, mas no Conforto do Alívio identifica-se a Reconstrução Mamária e Prótese. O Reconhecimento pelo Apoio Familiar e o Apoio Familiar remetem para a dimensão da Kolcaba no Conforto do Alívio e Tranquilidade e para o Contexto Social. A Procura de Informação encontra-se no Conforto do Alívio e Transcendência e no Contexto Social.

No Papel do Enfermeiro no Pós-mastectomia evidencia-se a Disponibilidade, Escuta Ativa, Empatia, Envolvimento Familiar, Desencadeamento do Envolvimento Familiar, Conforto, Facilitação da Capacitação e Apoio Social/ Articulação de Cuidados que se enquadram no Conforto do Alivio e Tranquilidade e no Contexto Social.

No Papel do Enfermeiro na Pré-mastectomia identifica-se o Conforto do Alivio e Tranquilidade, a Educação para a Saúde, Preocupação e Escuta Ativa encontrando-se os mesmos no Contexto Social. A Transmissão de Informação enquadra-se no Conforto da Transcendência para além do Conforto do Alívio e no Contexto Social.

\section{Conclusão}

O cancro de mama atinge a sexualidade feminina na sua dimensão física e emocional, já que a consequente cirurgia é mutiladora e, até mesmo o aparecimento de episódios de dor e efeitos colaterais do tratamento, alteram a autoimagem, o autoconceito, tendo repercussões negativas na identidade feminina e na família. 
The women with mastectomies and their families experience the mastectomy in unique ways. All of these deal with a change in current living conditions, especially in the expression of discomfort.

A dichotomy emerges between verbalized discomfort and promoting comfort; the latter, according to Kolcaba (1991), is the result of the meeting of basic human needs for relief, tranquillity and transcendence.

The findings allowed the identification of five categories: Feelings verbalized by Mastectomized Women, Impact Post-mastectomy, Adopted Strategies, Nurse's Role in pre and post mastectomy. These clarify that, in addition to the nursing interventions aimed at women subjected to mastectomy in the comfort / discomfort, it is also a necessity to take care of her family. The family requires care for understanding and help to overcome the transitions that this health-illness process of his partner and / or mother requires.

If our goal is to promote comfort to mastectomised woman and their families, it is essential to introduce comfort promotion strategies to enable the reduction of Negative Feelings such as Fear, Sadness, Death, Revolt, Loss, Shock, Disgust, Anguish, Uncertainty, Concern, Pain, Anxiety, Embarrassment, Inferiority, Insecurity, Negative Attitudes, Loss and Pain, and enhance Positive Feelings such as the Relief and Hope.

Therefore, the nurse should aim to help women with mastectomies to readjust to the new image, including the Mutilation, the need to Hide the Body, the whole Symbolism of Breast, the Decrease of Self-Esteem and the Confrontation with the Prosthesis.

Nurses should also enable integration as smoothly as possible in their family and / or social environments, ensuring an active involvement of the family, due to the Impact Post-mastectomy in Context (Confrontation with the Self, Drawback, Crisis/Impasse and Uncertainty Facing the Future), The Family Context (Shock, Interpersonal Relationship, Sexuality / Intimacy, Conjugality and Disability), Impact on Family Context in terms of Children (Interpersonal Relationship and Caring) and the Social Context (Confrontation).

To enable this integration, various strategies are adopted, namely Coping mechanisms (Recognition for Family Support, Family Support, Acceptance, Positive Attitude, Delivering Projects, Sharing, Information Search, Change of Individuality and Lived Clarification) and resources that contribute to improving the Self Concept (Breast Prosthesis and Reconstruction).

According to the above, the role of the nurse is crucial Post-mastectomy, as a professional Relational Competence (Availability, Active Listening, Empathy, Family Involvement and Initiation of the involvement of the same) and Instrumental Competence (Comfort, Facilitating Training and Social Support / Care Coordination) detector.
A mulher mastectomizada e a sua família vivenciam a mastectomia de forma singular. Todos estes lidam com uma alteração na sua condição de vida atual, nomeadamente na expressão dos desconfortos.

Emerge a dictomia entre o desconforto verbalizado e a promoção do conforto, sendo este último e, segundo Kolcaba (1991), o resultado do encontro das necessidades básicas humanas de alívio, tranquilidade e transcendência.

Os achados permitiram a identificação de cinco categorias: Sentimentos Verbalizados pelas Mulheres Mastectomizadas, Impacto Pós-mastectomia, Estratégias Adotadas, Papel do Enfermeiro no Pós e Pré-mastectomia. Estas clarificam que para além das intervenções de enfermagem dirigidas à mulher submetida a mastectomia no âmbito do conforto/desconforto é necessário incluir o familiar. A prestação de cuidados, não deve apenas focar a sua atenção na mulher, mas englobar a família que, também, necessita de compreensão e ajuda para ultrapassar as transições que este processo de saúde-doença da sua companheira e/ou mãe exige.

Se a nossa meta é a promoção do conforto à mulher mastectomizada e sua família, é fundamental introduzir estratégias de promoção de conforto para possibilitar a diminuição de Sentimentos Negativos como o Medo, Tristeza, Morte, Revolta, Perda, Choque, Repugnância, Angustia, Incerteza, Preocupação, Dor, Ansiedade, Embaraço, Inferioridade, Insegurança, Atitude Negativa, Perda e Dor, e potenciar Sentimentos Positivos como o Alívio e Esperança.

Por isso, o enfermeiro deve ter como objetivo ajudar a mulher mastectomizada a reajustar-se à nova imagem, nomeadamente à própria Mutilação, à necessidade de Esconder o Corpo, a todo o Simbolismo da Mama, à Diminuição da Autoestima e ao Confronto com a Prótese.

Deve ainda possibilitar a integração o melhor possível no seu meio familiar e/ou social, reconhecendo-se como tal, garantindo um envolvimento ativo da família, devido ao Impacto Pós-mastectomia no Contexto do Eu (Confronto com o Eu, Retrocesso, Crise/Impasse e Incerteza Face ao Futuro), no Contexto Familiar (Choque, Relação Interpessoal, Sexualidade/Intimidade, Conjugalidade e Incapacidade), Impacto no Contexto Familiar ao nível do Filhos (Relação Interpessoal e Inquietação) e no Contexto Social (Confronto).

Para possibilitar esta integração são diversas as Estratégias Adotadas, nomeadamente mecanismos de Coping (Reconhecimento pelo Apoio Familiar, Apoio Familiar, Aceitação, Atitude Positiva, Concretizar Projetos, Partilha, Procura de Informação, Alteração da Individualidade e Clarificação do Vivido) e recursos que contribuem para a melhoria da Autoimagem (Reconstrução Mamária e Prótese). 
The role of the nurse in the Pre-mastectomy phase, especially in Anticipatory Care (Health Education, Concern, Information Transmission and Active Listening) is significant.

Today, more than ever, the nursing care focused on women with mastectomies and their households is a challenge for nurses in the nursing affirmation as art and science, encouraging the highest level of quality in its praxis.

\section{Conflicts of interests}

The authors declare that there are no financial or personal relationships that could be viewed as potential conflict of interests.
De acordo com o exposto, é fundamental o Papel do Enfermeiro no Pós-mastectomia, como profissional detector de Competência Relacional (Disponibilidade, Escuta Ativa, Empatia, Envolvimento Familiar e Desencadeamento do envolvimento da mesma) e Competência Instrumental (Conforto, Facilitação da Capacitação e Apoio Social/Articulação de Cuidados).

É ainda relevante o Papel do Enfermeiro no Pré-mastectomia principalmente nos Cuidados Antecipatórios (Educação para a Saúde, Preocupação, Transmissão de Informação e Escuta Ativa).

Hoje, os cuidados de enfermagem centrados na mulher mastectomizada e no seu núcleo familiar são, mais do que nunca, um desafio para os enfermeiros, na afirmação da enfermagem como arte e ciência, fomentando o nível máximo de qualidade na sua praxis.

\section{Conflitos de Interesse}

Os autores declaram que não existem relações financeiras ou pessoais suscetíveis de serem vistas como potenciais conflitos de interesse. 


\section{References/ Referências}

[1] Seara, L. Função Sexual e Imagem Corporal da mulher mastectomizada. Revista Internacional de Andrología, 3:10 (2012), p.104110.

[2] Oliveira, M.; Monteiro, A. Mulheres mastectomizadas: ressignificação da existência. Texto Contexto Enfermagem, 3:13 (2004), p.401-408. Retrieved on 2015, february $12 \mathrm{http}: / /$ www.scielo.br/pdf/tce/v13n3/ a09v13n03.pdf.

[3] Pinheiro, P.; et al. Cancer in cancro em Portugal. IARC Technical Publication, 38 (2002). Retrieved on 2015 , february $12 \mathrm{https} / / /$ books. google.pt/books?id=MLJo9S86LBMC\&sit esec $=$ buy \&hl $=$ pt-PT\&source $=$ gbs vpt read

[4] Liga Portuguesa Contra o Cancro. Cancro da Mama. (2014). Retrieved on 2014, september $12 \mathrm{http} / / / \mathrm{www}$. ligacontracancro.pt/gca/ index.php?id=182.
[5] Santos, L.; Silva, L. Cancro da Mama. O que devemos saber? Do diagnóstico ao tratamento. Lisboa: Lidel; 2014.

[6] Kolcaba, K. A taxonomic structure for the concept comfort. 4:23 (1991) p. 237-240.

[7] Moniz, P., et al. Implicações da mastectomia na sexualidade e imagem corporal da mulher e resposta da enfermagem perioperatória. Revista de Enfermagem Referência, 3:III (2011). Retrieved on 2015, february 09 http://www.google.pt/url?sa $=t \& r c t=j \& q=\&$ esrc $=$ s\& source $=$ web\&cd $=4 \&$ ved $=0$ CGMQ FjAD\&url=http\%3A\%2F\%2Fwww.esenfc. pt $\% 2$ Frr $\% 2$ Fadmin $\% 2$ Fconteudos $\% 2$ Fdow nloadArtigo.php\%3Fid_ficheiro $\% 3 \mathrm{D} 400 \% 2$ 6codigo\%3D\&ei $=$ VXH7T72uBIr80QWOw bWoBw\&usg=AFQjCNHMLniqf3GU_52k WKL8UlrzV6xWyg.
[8] Kérouac, S. et al. El pensamiento enfermero. Barcelona: Masson, S.A; 2011.

[9] Watson, J. Enfermagem: Ciência humana e cuidar uma teoria de enfermagem. Loures: Lusociência; 2007.

[10] Figueiredo, M. Modelo Dinâmico de Avaliação e Intervenção Familiar. Loures: Lusociência; 2012

[11] Bardin, L. Análise de conteúdo, 3th ed. Lisboa: Edições 70; 2013. 